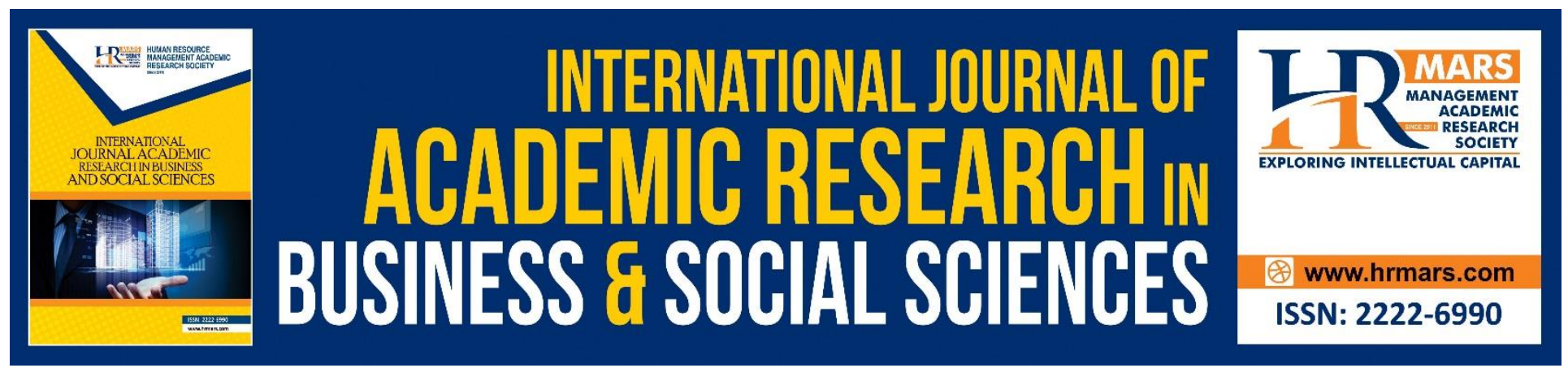

\title{
Knowledge, Attitude and Practice (KAP) on Haze among Secondary School Student in Hulu Langat, Selangor
}

\section{Haliza Abdul Rahman and Nur Hazami Shamsul Bahari}

To Link this Article: http://dx.doi.org/10.6007/IJARBSS/v10-i15/8243

DOI:10.6007/IJARBSS/v10-i15/8243

Received: 18 October 2020, Revised: 12 November 2020, Accepted: 30 November 2020

Published Online: 14 December 2020

In-Text Citation: (Rahman \& Bahari, 2020)

To Cite this Article: Rahman, H. A., \& Bahari, N. H. S. (2020). Knowledge, Attitude and Practice (KAP) on Haze among Secondary School Student in Hulu Langat, Selangor. International Journal of Academic Research in Business and Social Sciences, 10(15), 189-209.

Copyright: (C) 2020 The Author(s)

Published by Human Resource Management Academic Research Society (www.hrmars.com)

This article is published under the Creative Commons Attribution (CC BY 4.0) license. Anyone may reproduce, distribute, translate and create derivative works of this article (for both commercial and non-commercial purposes), subject to full attribution to the original publication and authors. The full terms of this license may be seen

at: http://creativecommons.org/licences/by/4.0/legalcode

Special Issue: Youth and Community Wellbeing: Issues, Challenges and Opportunities for Empowerment V1, 2020, Pg. 189 - 209

Full Terms \& Conditions of access and use can be found at http://hrmars.com/index.php/pages/detail/publication-ethics 


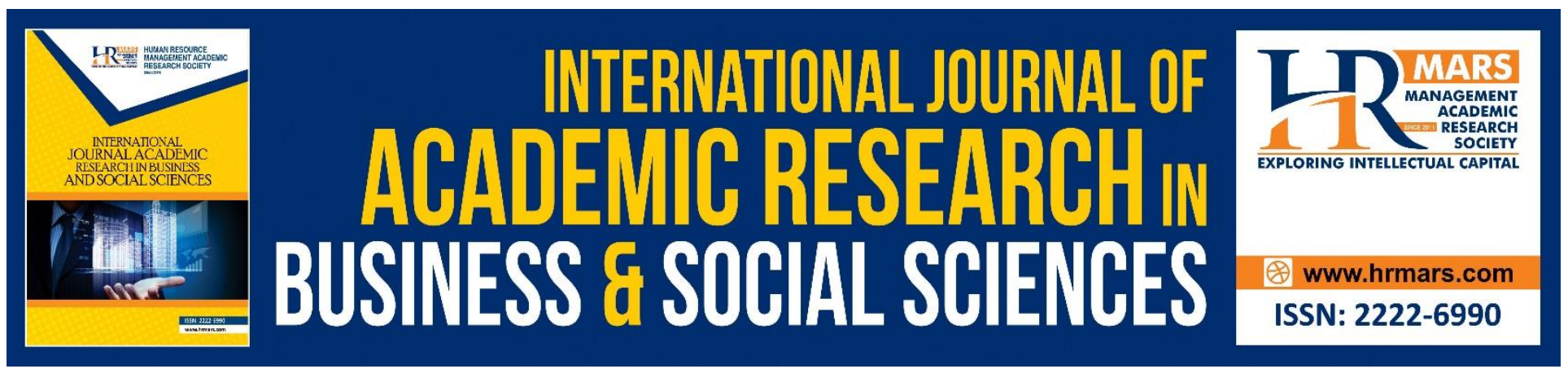

\title{
Knowledge, Attitude and Practice (KAP) on Haze among Secondary School Student in Hulu Langat, Selangor
}

\author{
1,2Haliza Abdul Rahman and ${ }^{2}$ Nur Hazami Shamsul Bahari \\ ${ }^{1}$ Institute for Social Sciences Studies, Putra InfoPort, Universiti Putra Malaysia, 43400 Serdang, \\ Selangor, Malaysia, ${ }^{2}$ Department of Environmental and Occupational Health, Faculty of Medicine \\ and Health Sciences, Universiti Putra Malaysia, Serdang, Selangor, Malaysia \\ Email: dr.haliza@upm.edu.my
}

\begin{abstract}
Haze has become an annual occurrence in Malaysia that sets back years ago starting from 1980s until recently in September 2019. Most people are affected by haze, as its impacts can cause from light to severe reaction(s), especially to the vulnerable group such as children, elderly and pregnant women etc. Hence, it is very crucial to equipped this susceptible group with enough protection so that they are able to minimize the risk from the exposure of haze. However, before all else, their current level of knowledge, attitude and practice on haze issues should be known, in order to create the suitable preventive measure(s) for them. Hence, a study of the knowledge, attitude and practices on haze between secondary school students in Hulu Langat, Selangor was conducted. A cross-sectional study design was used to determine the knowledge, attitude and practices on haze between two groups, which were Form 3 students and Form 5 students from Sekolah Menengah Kebangsaan (SMK) Perimbun. A set of modified questionnaires was administrated, and a total of 318 respondents were involved. This is to determine their sociodemographic characteristic, knowledge about haze, attitude towards haze, and practice during haze. Furthermore, 'Statistical Package for Social Sciences (SPSS) Version 22.0 was used to analysed the results. The results showed that the level of knowledge for Form 3 students and Form 5 students were moderate at 51 (81\%) and 197 (77.3\%) respectively. The level of attitude of Form 3 students and Form 5 students were again, moderate, at 44 (69.8\%) and $190(74.5 \%)$ respectively. Form 3 students and Form 5 students were also at a moderate level for practice during haze which were at $48(76.2 \%)$ and $204(80.0 \%)$ respectively. Furthermore, the results from Mann-Whitney $U$ test indicates, that there was only a significant difference on the level of knowledge $(z=-3.352, p=0.001)$ between Form 3 students and Form 5 students. While there was no significant difference between level of attitude $(z=-1.168, p=0.243)$ and level of practice $(z=-1.154$, $p=0.248$ ) among form 3 and form 5 students. Another Chi Square test was run and it reported that there was an association between attitude and practice $(p=0.018, p<0.05)$. In conclusion, Form 3
\end{abstract}


students and Form 5 students were deemed to have moderate knowledge and attitude and good practice on haze. Hence, it is recommended to enhanced the knowledge of these students as it could direct them towards a better attitude and practice during haze, and this can be done by reviewing the Environmental Education (EE) taught in school syllabus.

Keywords: Knowledge, Attitude, Practice, Haze, Secondary School Children

\section{Introduction}

Haze episode has been a significant problem as it has become a repeated event in South East Asia and this also includes Malaysia. Often, haze problem in Malaysia are linked with seasonal transboundary haze that came from Sumatra and Kalimantan, Indonesia. However, some of the major sources of haze are locally produced. For example, as reported that haze in Johan Setia has become a daily occurrence for the past decade and this is due to the open burning activity by the farmers that adapted the slash and burn agricultural practices (Chu, 2019). Hence, the haze event in Johan Setia, Selangor has worsened when the locally produced haze combines with the seasonal transboundary haze from forest fires in Indonesia.

The conceptual framework of this study was shown in Figure 1.1. Haze is one of the environmental pollutions. Liu et al. (2017) stated that haze factors can be divided into two, natural and anthropogenic. Some of the natural risk factors are ecological infrastructure, topography, meteorology and climate. While for anthropogenic, the risk factors are urban sprawl, transportation, economy and population. A study found out that there is a significant correlation between pollutants (PM2.5) concentration with urban's size, population, share of secondary and population density (Wang et al., 2017; Liu et al., 2017). In this study, one of the comparisons is between rural and urban. The study subject was secondary school children (student), aged 15 from lower form and aged 17 from upper form. 


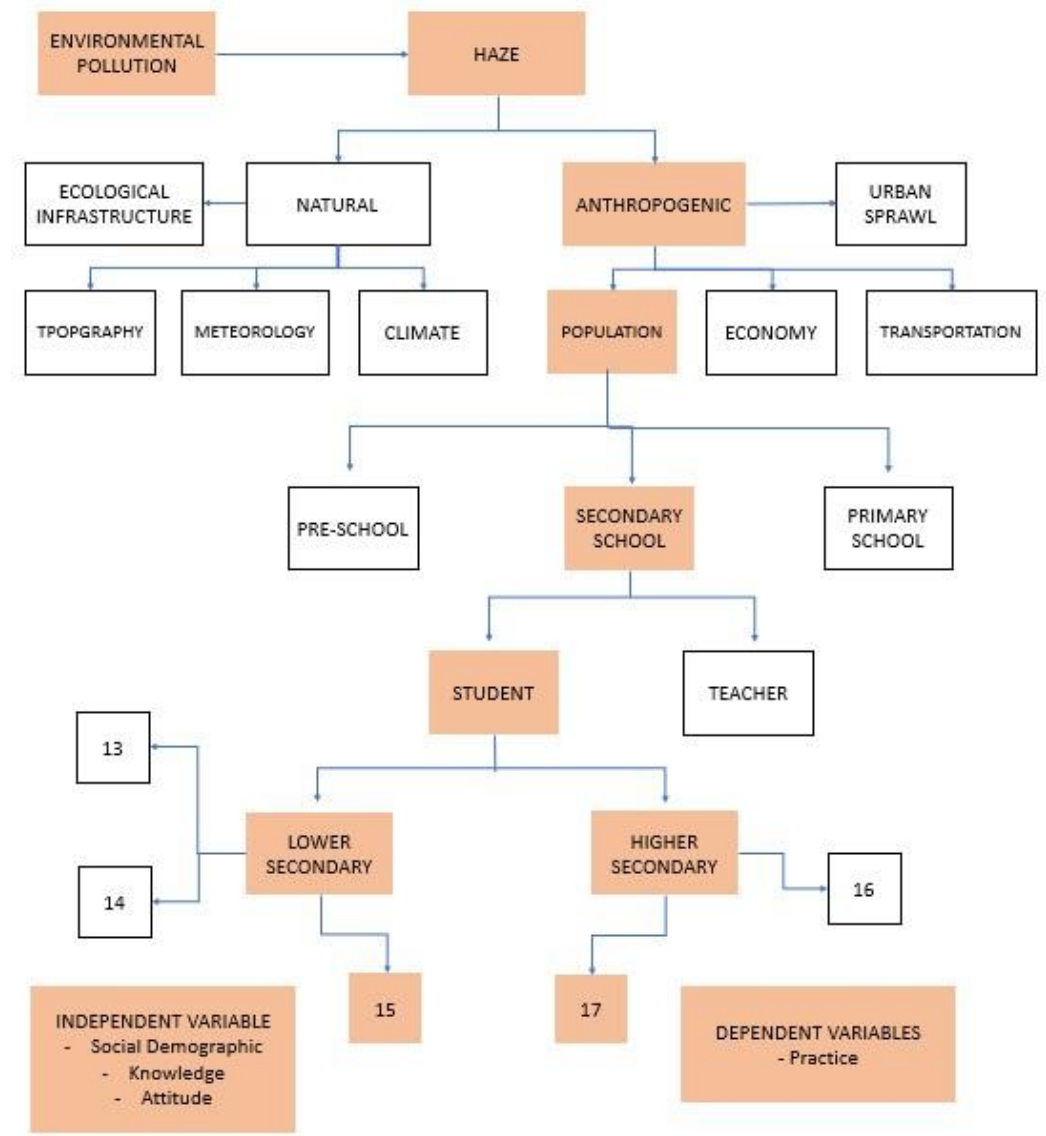

Figure 1.1: Conceptual Framework

Abdul Rahman (2002) has identified that these anthropogenic activities such as agriculture land clearings, open burning and forest fires are among the leading causative factor that worsen the visibility and the air quality (Norela, Saidah, \& Mahmud, 2013). He also stated that the pollutants collected during the haze, can have an adverse effect on human health and it came from anthropogenic sources such as industrial emissions, biomass combustion and motor vehicle (Abdul Rahman, 2002; Soleiman et al., 2003; (Norela et al., 2013)). Vehicle emission that was locally produced was contributing about 35\% of PM2.5 mass, which became the main source of haze (Rahman et al., 2015). On the other hand, studies found out that there is a strong correlation between the airborne particles (PM10) generated from burned biomass and the PM10 concentration at various air quality stations in Peninsular Malaysia (Mahmud, 2010; Othman, Sahani, Mahmud, \& Sheikh, 2014).

Haze can cause adverse effects to the human health, environment, economy and social. Ho et al. (2018) stated that some of the impacts are health effects, decreased in crop yield, accidents, loss of life, evacuations, preventive expenditures and loss of confidence of foreign investors (Ho et al., 2018). Even recently, an episode of haze has happened on September, 2019 that results in Air Pollution Index (API) to be up to more than 200, which indicates a very unhealthy level. Lack of knowledge, inattentive attitude and unsafe practices can increase a person's exposure to air pollution. A survey of knowledge, attitude and practice (KAP) on certain population of a specific area 
to a topic is done with the aim of collecting the data of its respondents known, believed and done. Hence, in order to support and build an evidence-based government policy that will help in seeking to improve health condition, an accurate and dependable of demographic correlates of KAP of atmosphere air pollution on health is crucial (Lim et al., 2012; Johnston et al., 2013; (Qian et al., 2016).

The Ministry of Education (MOE) has announced 7 days of school closure due to haze which were on the $12^{\text {th }}, 16^{\text {th }}, 17^{\text {th }}, 18^{\text {th }}, 19^{\text {th }}, 20^{\text {th }}, 21^{\text {st }}$ and $22^{\text {nd }}$ of September, 2019. In addition to that, Selangor recorded the highest number of school closure with 939 schools and followed by Sarawak with 373 schools (Ministry of Education, 2019). The API reading even reached unhealthy level, hence, at one time all schools in Selangor were ordered for closed. A study done by Othman et al. (2014), where results suggest that children and young adult have the highest marginal impact of PM10 (particles that has high correlation with burned biomass) on total inpatient cases. Other than that, a previous study had shown that people with a vast and higher education and literacy have higher levels of health knowledge than the people with lower level of education (Andrzejewsk, Reed \& White, 2009).

\section{Materials and Methods}

This study is a cross-sectional comparative study that design to make a comparison at a single point in time. This study is intended to focus on determining the knowledge, attitude and practices on haze among the secondary school children in Hulu Langat, Selangor. The total respondent involved in this study were 318, in which 255 were form 5 students, and another 63 were from form 3 students.

This study was conducted in one of the schools located in district Hulu Langat, which is Sekolah Menengah Kebangsaan (SMK) Perimbun, Cheras, Selangor. Secondary school students, specifically form 3 students and form 5 students were chosen because, they are one of the more susceptible groups towards haze effects. Two different age are chosen because it is to compare their KAP on haze from two different education level.

The respondents will be evaluated by using modified self-administered questionnaire which will assess their knowledge, attitude and practices on haze. The questionnaire will comprise of 4 sections. Section $A$ is about the social demographic of the respondents such as their age, gender and ethnicity. Next, in section $B$, the question will be asking more on the general information regarding haze phenomena. For section $C$, there will be 3 subtopics, 1) knowledge about haze, 2) attitude towards haze and 3) practice during haze. Lastly is section $D$, which is the suggestion to reduce haze.

The data obtained from the questionnaire was analysed by the Social Sciences Statistical Programme (SPSS). The level of KAP on haze was evaluated using scoring method as follow (Singh \& Chapman, 2011):

Table 1: scoring method for knowledge and practice

\begin{tabular}{|l|l|}
\hline \multicolumn{2}{|c|}{ Scoring } \\
\hline Right answer & 1 point \\
\hline Wrong answer & 0 point \\
\hline
\end{tabular}


Table 2: scoring method for attitude (positive statement)

\begin{tabular}{|l|l|}
\hline Scoring \\
\hline Strongly agree & 5 point \\
\hline Agree & 4 point \\
\hline Neutral & 3 point \\
\hline Disagree & 2 point \\
\hline Strongly disagree & 1 point \\
\hline
\end{tabular}

Table 3: scoring method for attitude (negative statement)

\begin{tabular}{|l|l|}
\hline \multicolumn{2}{|l|}{ Scoring } \\
\hline Strongly agree & 1 point \\
\hline Agree & 2 point \\
\hline Neutral & 3 point \\
\hline Disagree & 4 point \\
\hline Strongly disagree & 5 point \\
\hline
\end{tabular}

The scores obtained were converted in terms of score level and were categorized into three levels of knowledge, which were high level, moderate level and low level. a mean score with a standard error (SD), were used to sorted the scores into three level of knowledge:

$$
\begin{array}{ll}
\text { Good level } & \text { : score }>\text { Mean }+ \text { SD } \\
\text { Moderate level } & : \text { score }=\text { Mean }+/- \text { SD } \\
\text { Poor level } & \text { : score }<\text { Mean }- \text { SD }
\end{array}
$$

The respondents were classified after summing up the scores obtained, into three levels of low, moderate and high attitude. A mean score with a SD were used to categorized participants into these three levels, as follow (Singh \& Chapman, 2011):

$$
\begin{array}{lc}
\text { Good attitude } & \text { : score }>\text { Mean + SD } \\
\text { Moderate attitude } & \text { : score = Mean+/ - SD } \\
\text { Poor attitude } & \text { : score < Mean - SD }
\end{array}
$$

The scoring method was used to grouped the subjects into two level of practice. Dichotomous (yes/no) scoring was used on the practice of subjects during haze. Practice score were summed up and translate into score level. From there, the subjects will be classified into two level, using the mean score and SD (Singh \& Chapman, 2011):

Good level : score > Mean

Poor level : Score $<$ Mean 
Descriptive statistical of data was used to determine mean and standard deviation. Chi-square was also be used to determine the association between two different groups. Whereas Mann UWhitney was used to compare two groups of respondents. Before conducting the study, the approval from the Ethical Committee for UPM (JKEUPM) was gained [JKEUPM-2020-014].

The reliability of the questionnaire was assured through a pilot study. It was conducted by distributing a sample of the questionnaire among 26 secondary school students who had similar characteristics with the sample subject as the representative of the respondents. The main objective for this pre-test is to ensure that the respondents could understand the question, as well as to find any problem that could arise while answering the question. The Cronbach alpha obtained from the pilot study was 0.828 . Thus, the questions were considered reliable.

\section{Result and Discussion}

\section{General Socio-Demographic Characteristic}

This part showed how different group of students with different socio-demographic characteristics had different level of knowledge, attitude and practice during haze. For age, all form 3 students are 15-years old which were 63 (19.8\%), and all form 5 students are 17-years old which were 255 (80.2\%). Regarding gender, 29 (46.0\%) were male and 34 (54.0) were female for form 3 students. While for form 5 students, there were 109 (42.7\%) of male respondents and $146(57.3)$ of female respondents. These numbers are consistent with the numbers of enrolment at Secondary level reported by Minister of Education (2018), which stated that the number of female enrolments for form 3 students and form 5 students were higher as compared to the number of male enrolments.

As for race, the total number of respondents for both Malay and Chinese students were nearly equal with each other. Form 3 students were dominated by Malay students at 59 (93.7\%), followed by the Chinese students at $3(4.8 \%)$, then the Indian students with only $1(1.6 \%)$ respondents and zero respondents from other race. While for form 5 students, it was dominated by the Chinese students with 144 (56.5\%) participants, followed by the Malay students at 89 (34.9) participants, the Indian students at 15 (5.9\%) and lastly from other race with $5(2.0 \%)$ participants.

Four socio-economic status (SES) variables were analysed in this research, including father's education level, mother's education level, monthly household income and household size. For form 3 students, the most of students' fathers and mothers have tertiary education at 24 (38.1\%) and 20 (31.7), respectively. On the other hand, for form 5 students, most of the student's father's and mother's highest educational level was secondary education at 97 (38.0\%) and 98 (22.2\%) respectively.

The monthly household income was also summarized in figure 4.1 as it shows the distribution of the sample. On a scale of 1 to 5 ( 5 being the highest) the average monthly household income for form 3 students and form 5 students were 3.94 and 3.74, respectively, in which it translates into income starting from RM 2001 to RM 3000. In accordance with the 2019 methodology, the national mean poverty line income (PLI) value was RM 2208 per months (DOSM, 2020). PLI is the level of income that is just sufficient to obtain the minimum necessities of life and basic needs which includes both food and non-food items. If he or her income is below the PLI, that person or household can be considered poor (Mat Zin, 2007). In regard to the above statement, the PLI is in between the range of the average monthly household income. 
The last SES variables collected was the household size. The distribution of household size can be seen in figure 4.1. For form 3 students, the average household size for form 3 students was 2.66 which can be interpret as 6 to 7 people in a house. While, for form 5 students, the average household size was 2.22, and can be interpret as 4 to 5 people in a house. Based on the Department of Statistic Malaysia, in the 2010 Census, the average household size reported was 4.31 people. However, in accordance to the 2019 methodology, DOSM reported the national mean PLI value was RM 2208 per month with an average household size of 3.9 person. Moreover, 70.4 percent of the 405,441 poor household having more than four household members, while 13.3 per cent of it had four household members (Ida, 2020). This statement corresponds with a report from HIS/BA (2014) which showed that absolute poverty is higher among household with five or more members than it was among household with four members or less (DOSM, 2015, P. 84; (Redmond, Praino, \& Siddiquee, 2016)

\section{Knowledge, Attitude and Practice on Haze Knowledge on Haze}

A mean score of 8.0314 with a standard error (SD) of 1.47287, were used to sorted the scores into three level of knowledge, as shown below:

$$
\begin{aligned}
& \text { Good level : score of } 10 \\
& \text { Moderate level: score between } 6 \text { - } 9 \\
& \text { Low level : score of } 5 \text { or below }
\end{aligned}
$$

For form 3 students and form 5 students, most of them had moderate levels of knowledge, at 51 (81\%) and 197 (77.3\%), respectively. The next highest number of respondents of Form 3 students has low level of knowledge, at 9 (14.3\%) and followed by students with high level of knowledge at 3 (4.8\%). On the other hand, the second highest number of respondents of form 5 students has high level of knowledge, with 45 (17.6), then followed by low level of knowledge with 13 (5.1\%) respondents.

There are still a number of students from both groups who showed low level of knowledge, even though, haze is a recurrent phenomenon, that happens every year. Hence, it is a little bit worrisome that these respondents may not be interested in gaining knowledge and information about something that can cause adverse health effects if they keep on being ignorant to the issues surrounding them.

These findings were aligned with previous studies that shows age may or may not have something to do with the knowledge. Pretto, Acreman and Ashfold (2015) reported that younger respondents scored lesser in awareness than older respondents, hence, age correlate with awareness but not with concern (Pretto, Acreman, \& Ashfold, 2015). Other study reported a significant variation in KAP scores according to age. However, there were other studies who shows contrast result, by stating that younger groups score higher in their KAP (Yezli et al., 2019).

Blanaid et al. (2002) stated that based on the educational theory, the internal domains of learning are cognitive aspects that refers to achieving the right factual knowledge, affective aspect refers attitudes and beliefs and behavioral aspect refres to conducting behavior in question and changing behavior relies on this theory (Tolvanen, Lahti, Miettunen, \& Hausen, 2012). Tolvanen et. 
INTERNATIONAL JOURNAL OF ACADEMIC RESEARCH IN BUSINESS AND SOCIAL SCIENCES

Vol. 10, No. 15, Youth and Community Wellbeing: Issues, Challenges and Opportunities for Empowerment V1. 2020, E-ISSN: 2222-6990 @) 2020 HRMARS

al, (2012) reported that by improving knowledge, the success rate of changing attitudes and behavior increased. Al Binali et al. (2010) also stated something similar, which was, the increase of knowledge focuses more on the changes of behaviour and practices (Al Binali, Mahfouz, Al Fifi, Naser, \& Al Gelban, 2010).

\section{Attitude towards Haze}

A mean score of 59.2767 with a SD of 7.9151 were used to categorized participants into these three levels, as follow:

$\begin{array}{ll}\text { Good level } & \text { : score of } 68 \text { or more } \\ \text { Moderate level } & \text { : score between } 51-67 \\ \text { Low level } & \text { : score of } 50 \text { or below }\end{array}$

The level of attitude was distributed and tabulated. Majority from both of form 3 students and form 5 students had moderate attitude towards haze, with 44 (69.8\%) and 190 (74.5\%), respectively. The second highest number of form3 students, showed high attitude, at 12 (19\%), and then, followed by students with low level of attitude, with $7(11.1 \%)$. On the contrary, for form 5 students, their second highest number of students showed low attitude, at 37 (14.5\%), and then followed by students with high level of attitude, at 28 (11\%).

A research done by Tolvanen et al. 2012) had reported that knowledge affects the behaviour, however, it was mostly through attitudes. If we were to define attitude, it is Attitude is a disposition or tendency to respond positively or negatively towards a specific thing such as an idea, object, person, or situation (Wong et. al, 2019). Hence this tendency to react is how influencing attitude with enough positive and correct knowledge, will then produces good practices. This statement can be supported by previous studies by Barr (2007) shows that there is an association between knowledge and positive attitude. Hence, an increase in knowledge level is proportional with the increase of positive attitude (Barr, 2007; Chen et al., 2011; Aminrad et al., 2013).

\section{Practice During Haze}

A mean score of 9.0692 and SD of 2.17853 were used to categorized participants into these two levels, as follow:

Good level : score of 9 or more

Poor level : Score of 8 or below

The distribution of level of practice during haze among form 3 students and form 5 students were analysed and distributed. Most of form3 students and form 5 students had showed good practice during haze, at $38(60.3 \%)$ and 151 (59.2\%), respectively. While for poor practice during haze, there were 25 (39.7\%) of form 3 students and 104 (40.8\%) of form 5 students.

It was quite alarming to see that near half of form 3 students and form 5 students showcased poor practice during haze. As this portrays the actions and this could lead them to attaining more adverse health effects. Practice is defined as the way in which people demonstrate their knowledge and attitude through their actions (Kaliyaperumal, Expert, \& Project, 2004). Therefore, it could be said that to change from poor practice to good practice, could be the results of changing the knowledge and attitude. This statement was supported by a research done that stated by Kollmuss and Agyeman (2002), changes in environmental behaviour and human practices towards nature are 
INTERNATIONAL JOURNAL OF ACADEMIC RESEARCH IN BUSINESS AND SOCIAL SCIENCES

Vol. 10, No. 15, Youth and Community Wellbeing: Issues, Challenges and Opportunities for Empowerment V1. 2020, E-ISSN: 2222-6990 @) 2020 HRMARS

strongly influenced by the increased of knowledge and awareness about environmental dilemma (; (Hammami et al., 2017). However, based on other studies, they stated that changing a practice was a process, and may not change overnight. Practice refers to the changes of behaviour in regards to health may be the results of some factors such as growing up (development, skill development), learning, conditioning or extrinsic and intrinsic rewards. These changes are considered a process. This process can be influenced by various internal factors such as knowledge, attitudes, intention and stress, and external factors, such as social support and environment (Blanaid et al., 2002; Christian and Holger, 2005; Ralph J et al., 2005; Tolvanen et. al, 2012)

\section{Comparison of the Knowledge, Attitude and Practice of Haze Among Form 3 Students and Form 5 Students}

The knowledge score was not normally distributed, with the $p$-value of KolmogorovSmirnov(KS) was 0.000 . Hence, Mann-Whitney $U$ test was used to compare the differences in knowledge's score between Form 3 students and Form 5 students. The mean ranks for form 3 students was 125.58 , while mean rank for form 5 students was 167.88 . The higher the score, the higher the mean ranks. Hence, form 5 students have a higher knowledge score than form 3 students. Based on Mann-Whitney u test, the $Z$ statistic was -3.352 , with a $p$-value of 0.001 . As the $p$-value was $<0.05$, therefore, the null hypothesis was rejected and the results was significant. Thus, knowledge scores for from 5 students $(M d n=8)$ were higher than form 3 students $(M d n=8)$. This test indicated that this difference was statistically significant, $U\left(N_{\text {form } 5}=225, N_{\text {form } 3}=63\right)=5895.5, Z=-3.352, p<$ 0.001 .

Table 4: Comparison of the knowledge on haze between form 3 students and form 5 students

\begin{tabular}{lccccccc}
\hline & Group & $\mathrm{N}$ & $\begin{array}{c}\text { Median } \\
(\mathrm{IQR})\end{array}$ & Mean Rank & $\begin{array}{c}\text { Mann- } \\
\text { Whitney U }\end{array}$ & $\begin{array}{c}\text { Z- } \\
\text { statistic }\end{array}$ & $\begin{array}{l}\mathrm{p} \text { - } \\
\text { value }\end{array}$ \\
\hline Total Score form & 363 & $8(3)$ & 125.58 & 5895.5 & -3.352 & $0.001^{*}$ \\
knowledge form 5 & 255 & $8(2)$ & 167.88 & & & \\
\hline
\end{tabular}

$\mathrm{N}=318$, Mann Whitney Test *significant at <.05

The finding concludes that form 5 students have statistically significantly higher knowledge score than form 3 students. This can be said because, generally speaking, form 5 students had more years of learning environmental education. Environment Education (EE) has been introduced and infused informally and formally in national system of Education. EE was introduced stating with primary school children, standard 3 to standard 6. It was later on introduced to the secondary school students, aged 13 to 17 years old. EE in secondary school children was not made as a single subject, however, was intergrated into different subjects, such as in geography, (Lateh \& Muniandy, 2010), as science, moral education, and life skills (Said, Yahaya, \& Ahmadun, 2007). For form 3 students, Geography and Science subjects were said to be the main subjects that gave the most information and knowledge about the environment. For upper form (form 4 and form 5), Science was rated the highest, particularly Biology (Said, Yahaya, and Ahmadun, 2007). Due to their own interest, students might neglect EE as they no longer need to learn the subjects (Habibah Lateh, et. al., 2009; Lateh and Muniandy, 2010). 
The $p$-value of Kolmogorov-Smirnov (KS) for attitude score was 0.000 . This showed that it was not normally distributed. Thus, Mann-Whitney $U$ test was used to determine the significant difference in attitude score between form 3 students and form 5 students. The mean rank of form 3 students was 171.6 while mean rank for form 5 students was 156.51. The higher the score, the higher the mean ranks. Hence, form 3 students have a higher attitude score than form 5 students. According to the Mann-Whitney $U$ test being done, the Z-statistic was -1.168 with a $p$-value of 0.243 , which was $>0.05$. Hence, the null hypothesis was not rejected and the result was not significant. We can conclude that there was no significant difference of median attitude between form 5 students ( $M d n$ $=60)$ and form 3 students $(M d n=62)$. This test indicated that this difference was not statistically significant, $U\left(N_{\text {form } 5}=225, N_{\text {form } 3}=63\right)=7270, z=-1.168, p=.243$.

Table 5: Comparison of the attitude towards haze between form 3 students and form 5 students

\begin{tabular}{cccccccc}
\hline & Group & $\mathrm{N}$ & $\begin{array}{c}\text { Median } \\
\text { (IQR) }\end{array}$ & Mean Rank & $\begin{array}{c}\text { Mann- } \\
\text { Whitney U }\end{array}$ & Z-statistic & $\begin{array}{c}\mathrm{p} \text { - } \\
\text { value }\end{array}$ \\
\hline Total Score form & 363 & $62(11)$ & 171.6 & 7270 & -1.168 & 0.243 \\
attitude $\quad$ form 5 & 255 & $60(10)$ & 156.51 & & & \\
\hline
\end{tabular}

$\mathrm{N}=318$, Mann Whitney Test

The knowledge score was not normally distributed, with the $p$-value of Kolmogorov-Smirnov (KS) was 0.000 . Hence, Mann-Whitney $U$ test was used. For form 3 students, the mean rank of practice score was 171.35 while for form 5 students was 156.57. the mean rank indicates which group can be consider as having higher score, which namely, is the group with highest mean rank and in the case, form 3 students have a higher practice score than form 5 students. Based on Mann-Whitney $U$ test, the Z-statistic was -1.154 and the $p$-value was 0.248 , which was $>0.05$. Hence, the null hypothesis was not rejected and the result was not significant. We can conclude that there was no significant difference of median practice between form 5 students $(M d n=9)$ and form 3 students $(M d n=10)$. This test indicated that this difference was not statistically significant, $U\left(N_{\text {form } 5}=225, N_{\text {form } 3}=63\right)=$ $7286, Z=-1.154, p=0.248$.

Table 6: Comparison of the practice during haze between form 3 students and form $\mathbf{5}$ students

\begin{tabular}{lccccccc}
\hline & Group & $\mathrm{N}$ & $\begin{array}{c}\text { Median } \\
(\text { IQR) }\end{array}$ & Mean Rank & $\begin{array}{c}\text { Mann- } \\
\text { Whitney U }\end{array}$ & Z-statistic & $\begin{array}{l}\text { p- } \\
\text { value }\end{array}$ \\
\hline Total Score form & 3 & 63 & $10(3)$ & 171.35 & 7286 & -1.154 & 0.248 \\
practice $\quad$ form 5 & 255 & $9(3)$ & 156.57 & & & \\
\hline
\end{tabular}

$\mathrm{N}=318$, Mann Whitney Test

\section{Association between Socio-demographic characteristic with Student's Knowledge, Attitude and Practice}

The social-demographic characteristic collected in this study were, age, gender, race, group (form), father's education, mother's education, household income and household size. The last four variables can be measure as a dimension of Socio-economic status. The association between 
INTERNATIONAL JOURNAL OF ACADEMIC RESEARCH IN BUSINESS AND SOCIAL SCIENCES

Vol. 10, No. 15, Youth and Community Wellbeing: Issues, Challenges and Opportunities for Empowerment V1. 2020, E-ISSN: 2222-6990 @ 2020 HRMARS

sociodemographic characteristic and student's knowledge, attitude and practice were analysed by using ChiSquare test, or also known as Pearson's chi-square. This however, exclude age and group(form) from the analysis, as all form 3 students are 15 years old, and all form 5 students are 17 years old. Chi-square test is used to test the relationship and determine whether two categorical variables are associated in some manner.

There were no association between all of the social demographic characteristic (gender, race, father's education, mother's education, household income and household size) with knowledge among form 3 students and form 5 students. In the Tables 4 and Table 5 below, it shows that that all the $p$-value of the selected variables were more than the desired significance threshold $(p>0.05)$. Null hypothesis was not rejected, hence, there was no significant relationship between social demographic characteristic (age, gender, race, group (form), father's education, mother's education, household income and household size) and the knowledge among form 3 students and form 5 students.

Table 7: Association between socio-demographic with knowledge among Form 3 students

\begin{tabular}{|c|c|c|c|c|c|c|}
\hline \multirow[b]{2}{*}{ Gender } & \multicolumn{6}{|c|}{ Knowledge level, n(\%) } \\
\hline & Low & Moderate & High & $X 2(d f)$ & $p$-value & $\mathrm{N}$ \\
\hline Male & $5(7.9)$ & $22(34.9)$ & $2(3.2)$ & $1.015(2)$ & 0.602 & 63 \\
\hline Female & $4(6.3)$ & $29(46.0)$ & $1(1.6)$ & & & \\
\hline \multicolumn{7}{|l|}{ Race } \\
\hline Malay & $8(12.7)$ & $48(76.2)$ & $3(4.8)$ & $1.252(4)$ & 0.87 & 63 \\
\hline Chinese & $1(1.6)$ & $2(3.2)$ & $0(0)$ & & & \\
\hline Indian & $0(0)$ & $0(0)$ & $0(0)$ & & & \\
\hline Others & $0(0)$ & $1(1.6)$ & $0(0)$ & & & \\
\hline \multicolumn{7}{|l|}{ Father's Education } \\
\hline No formal education & $0(0)$ & $0(0)$ & $0(0)$ & $2.674(2)$ & 0.263 & 35 \\
\hline Primary education & $0(0)$ & $0(0)$ & $0(0)$ & & & \\
\hline Secondary education & $0(0)$ & $9(25.7)$ & $2(5.7)$ & & & \\
\hline Tertiary education & $2(5.7)$ & $21(60)$ & $1(2.9)$ & & & \\
\hline \multicolumn{7}{|l|}{ Mother's education } \\
\hline No formal education & $0(0)$ & $0(0)$ & $0(0)$ & $2.442(4)$ & 0.655 & 35 \\
\hline Primary education & $0(0)$ & $1(2.9)$ & $0(0)$ & & & \\
\hline Secondary education & $0(0)$ & $12(34.3)$ & $2(5.7)$ & & & \\
\hline Tertiary education & $2(5.7)$ & $17(48.6)$ & $1(2.9)$ & & & \\
\hline \multicolumn{7}{|l|}{ Household Income (MYR) } \\
\hline$<1000$ & $0(0)$ & $1(2.9)$ & $0(0)$ & $14.667(8)$ & 0.066 & 35 \\
\hline $1001-2000$ & $0(0)$ & $4(11.4)$ & $0(0)$ & & & \\
\hline $2001-3000$ & $2(5.7)$ & $4(11.4)$ & $1(2.9)$ & & & \\
\hline $3001-4000$ & $0(0)$ & $5(14.3)$ & $2(5.7)$ & & & \\
\hline$>4001$ & $0(0)$ & $16(45.7)$ & $0(0)$ & & & \\
\hline \multicolumn{7}{|l|}{ Household Size 1 -3 } \\
\hline people & $0(0)$ & $1(2.9)$ & $1(2.9)$ & $7.775(6)$ & 0.255 & 35 \\
\hline
\end{tabular}


INTERNATIONAL JOURNAL OF ACADEMIC RESEARCH IN BUSINESS AND SOCIAL SCIENCES

Vol. 10, No. 15, Youth and Community Wellbeing: Issues, Challenges and Opportunities for Empowerment V1. 2020, E-ISSN: 2222-6990 @ 2020 HRMARS

\begin{tabular}{lccc}
4 - 5 people & $1(2.9)$ & $11(31.4)$ & $1(2.9)$ \\
6 - 7 people & $0(0)$ & $14(40.0)$ & $1(2.9)$ \\
$>8$ people & $1(2.9)$ & $4(11.4)$ & $0(0)$ \\
\hline
\end{tabular}

Chi-Square test

Table 8 : Association between socio-demographic with knowledge among Form 5 students

\begin{tabular}{|c|c|c|c|c|c|c|}
\hline \multirow[b]{2}{*}{ Gender } & \multicolumn{6}{|c|}{ Knowledge level, n(\%) } \\
\hline & Low & Moderate & High & $\mathrm{X} 2$ (df) & $p$-value & $\mathrm{N}$ \\
\hline Male & $8(3.1)$ & $83(32.5)$ & $18(17.1)$ & $1.015(2)$ & 0.602 & 255 \\
\hline Female & $5(2)$ & $114(44.7)$ & $27(10.6)$ & & & \\
\hline \multicolumn{7}{|l|}{ Race } \\
\hline Malay & $6(2.4)$ & $67(26.5)$ & $17(6.7)$ & $4.082(6)$ & 0.666 & 255 \\
\hline Chinese & $7(2.8)$ & $111(43.5)$ & $27(10.6)$ & & & \\
\hline Indian & $0(0)$ & $14(5.5)$ & $1(0.4)$ & & & \\
\hline Others & $0(0)$ & $5(2.0)$ & $0(0)$ & & & \\
\hline \multicolumn{7}{|l|}{ Father's Education } \\
\hline No formal education & $0(0)$ & $6(2.4)$ & $1(0.4)$ & $5.408(6)$ & 0.493 & 247 \\
\hline Primary education & $4(1.6)$ & $48(19.4)$ & $6(2.4)$ & & & \\
\hline Secondary education & $4(1.6)$ & $71(31.7)$ & $22(8.9)$ & & & \\
\hline Tertiary education & $3(1.2)$ & $69(27.9)$ & $13(5.3)$ & & & \\
\hline \multicolumn{7}{|l|}{ Mother's education } \\
\hline No formal education & $1(0.4)$ & $8(3.3)$ & $2(0.8)$ & $7.767(8)$ & 0.457 & 246 \\
\hline Primary education & $5(2.0)$ & $42(17.1)$ & $5(2.0)$ & & & \\
\hline Secondary education & $2(0.8)$ & $78(31.7)$ & $18(7.3)$ & & & \\
\hline Tertiary education & $3(1.2)$ & $64(26)$ & $17(6.9)$ & & & \\
\hline \multicolumn{7}{|c|}{ Household Income (MYR) } \\
\hline$<1000$ & $2(0.8)$ & $11(4.5)$ & $1(0.4)$ & $6.104(8)$ & 0.636 & 246 \\
\hline $1001-2000$ & $1(0.4)$ & $28(11.4)$ & $5(2.0)$ & & & \\
\hline $2001-3000$ & $2(0.8)$ & 42(17.1) & $8(3.3)$ & & & \\
\hline $3001-4000$ & $3(1.2)$ & $36(14.6)$ & $20(8.1)$ & & & \\
\hline$>4001$ & $3(1.2)$ & $74(30.1)$ & $20(8.1)$ & & & \\
\hline \multicolumn{7}{|l|}{ Household Size } \\
\hline 1 -3 people & $1(0.4)$ & 19(7.6) & $7(2.8)$ & $8.119(6)$ & 0.23 & 250 \\
\hline 4 - 5 people & $1(0.4)$ & $118(47.2)$ & $26(17.3)$ & & & \\
\hline 6 - 7 people & $4(1.6)$ & $51(20.4)$ & $9(14.1)$ & & & \\
\hline$>8$ people & $2(0.8)$ & $5(2.0)$ & $2(0.8)$ & & & \\
\hline
\end{tabular}

Chi-Square test

For the attitude towards haze, there were only two variables that showed significant results. The first variable was gender. There was an association between gender and attitude towards haze among form 5 students, $X^{2}(2, N=255)=8.794, p=.012$. The null hypothesis was rejected and the result was significant. For the effect size of a chi-square independence test, Cramer's V was 0.186. 
INTERNATIONAL JOURNAL OF ACADEMIC RESEARCH IN BUSINESS AND SOCIAL SCIENCES

Vol. 10, No. 15, Youth and Community Wellbeing: Issues, Challenges and Opportunities for Empowerment V1. 2020, E-ISSN: 2222-6990 @ 2020 HRMARS

Since Cramer's $V$ takes on values between 0 and 1, 0.186 indicates a very weak association. The second variable was race. The relation between race and attitude was significant among form 5 students. The $p$-value for association between race and attitude was taken from Fisher's Exact test, which was a two-sided $p$ value $=.024$. Fisher's Exact test was used because the assumption of no more than $20 \%$ of all cells may have expected frequencies $<5$ was violated. The null hypothesis was rejected and the result was significant. For the effect size of a chi-square independence test, Cramer's was 0.163 . Since Cramer's V takes on values between 0 and $1,0.163$ indicates a very weak association.

The rest of the variables, after analysed using the chi-square test of independence showed that there was no significant association between other socio-demographic characteristic (father's education, mother's education, household income and household size) and attitude towards haze among form 5 students. On the other hand, for form 3 students, there were no association between all of the social demographic characteristic (gender, race, father's education, mother's education, household income and household size) with attitude towards haze. All the p-value of the selected variables were more than the desired significance threshold $(p>0.05)$. Therefore, the null hypothesis was not rejected and the results were not significant.

Table 9: Association between socio-demographic with attitude among Form 3 students

\begin{tabular}{|c|c|c|c|c|c|c|}
\hline \multicolumn{7}{|c|}{ Attitude level, $\mathrm{n}(\%)$} \\
\hline Gender & Low & Moderate & High & $X 2(d f)$ & $p$-value & $\mathrm{N}$ \\
\hline Male & $5(7.9)$ & $20(31.7)$ & $4(6.3)$ & $2.602(2)$ & 0.272 & 63 \\
\hline Female & $2(3.2)$ & $24(38.1)$ & $8(12.7)$ & & & \\
\hline \multicolumn{7}{|l|}{ Race } \\
\hline Malay & $7(11.1)$ & $41(65.1)$ & $11(17.5)$ & $1.127(4)$ & 0.89 & 63 \\
\hline Chinese & $0(0)$ & $2(3.2)$ & $1(1.6)$ & & & \\
\hline Indian & $0(0)$ & $1(1.6)$ & $0(0)$ & & & \\
\hline Others & $0(0)$ & $0(0)$ & $0(0)$ & & & \\
\hline \multicolumn{7}{|l|}{ Father's Education } \\
\hline No formal education & $0(0)$ & $0(0)$ & $0(0)$ & & & 35 \\
\hline Primary education & $0(0)$ & $0(0)$ & $0(0)$ & & & \\
\hline Secondary education & $0(0)$ & $7(20)$ & $4(11.4)$ & $0.952(1)$ & 0.329 & \\
\hline Tertiary education & $0(0)$ & $19(54.3)$ & $5(14.3)$ & & & \\
\hline \multicolumn{7}{|l|}{ Mother's education No } \\
\hline formal education & $0(0)$ & $0(0)$ & $0(0)$ & $1.421(2)$ & 0.491 & 35 \\
\hline Primary education & $0(0)$ & $1(2.9)$ & $1(2.9)$ & & & \\
\hline Secondary education & $0(0)$ & $9(25.7)$ & $5(14.3)$ & & & \\
\hline Tertiary education & $0(0)$ & $16(47.7)$ & $4(11.4)$ & & & \\
\hline \multicolumn{7}{|c|}{ Household Income (MYR) } \\
\hline$<1000$ & $0(0)$ & $1(2.9)$ & $0(0)$ & $1.112(4)$ & 0.892 & 35 \\
\hline $1001-2000$ & $0(0)$ & $3(8.6)$ & $1(2.9)$ & & & \\
\hline $2001-3000$ & $0(0)$ & $5(14.3)$ & $2(5.7)$ & & & \\
\hline $3001-4000$ & $0(0)$ & $6(17.1)$ & $1(2.9)$ & & & \\
\hline$>4001$ & $0(0)$ & $11(31.4)$ & $5(14.3)$ & & & \\
\hline
\end{tabular}


INTERNATIONAL JOURNAL OF ACADEMIC RESEARCH IN BUSINESS AND SOCIAL SCIENCES

Vol. 10, No. 15, Youth and Community Wellbeing: Issues, Challenges and Opportunities for Empowerment V1. 2020, E-ISSN: 2222-6990 @ 2020 HRMARS

Household Size $1-3$

\begin{tabular}{lcccccc}
$\quad$ people & $0(0)$ & $1(2.9)$ & $1(2.9)$ & $4.677(3)$ & 0.197 & 35 \\
4 - 5 people & $0(0)$ & $11(31.4)$ & $2(5.7)$ & & & \\
6 - 7 people & $0(0)$ & $12(34.3)$ & $3(8.6)$ & & \\
$>8$ people & $0(0)$ & $2(5.7)$ & $3(8.6)$ & & \\
\hline
\end{tabular}

Chi-Square test

Table 10: Association between socio-demographic with attitude among Form 5 students

\begin{tabular}{|c|c|c|c|c|c|c|}
\hline \multicolumn{7}{|c|}{ Attitude level, n(\%) } \\
\hline Gender & Low & Moderate & High & $X 2(d f)$ & $p$-value & $\mathrm{N}$ \\
\hline Male & $24(9.4)$ & $75(29.4)$ & $10(3.9)$ & $8.794(2)$ & $0.012 *$ & 255 \\
\hline Female & $13(5.1)$ & $115(45.1)$ & $18(7.1)$ & & & \\
\hline \multicolumn{7}{|l|}{ Race } \\
\hline Malay & $7(2.7)$ & $69(27.12)$ & $14(5.5)$ & $13.417(6)$ & $0.024^{*}$ & 255 \\
\hline Chinese & $26(10.2)$ & $107(42.0)$ & $12(4.7)$ & & & \\
\hline Indian & $3(1.2)$ & $12(4.7)$ & $0(0)$ & & & \\
\hline Others & $1(0.4)$ & $2(0.8)$ & $2(0.8)$ & & & \\
\hline \multicolumn{7}{|l|}{ Father's Education } \\
\hline No formal education & $2(0.8)$ & $4(1.6)$ & $1(0.4)$ & $4.399(6)$ & 0.623 & 247 \\
\hline Primary education & $8(3.2)$ & $41(16.6)$ & $9(3.6)$ & & & \\
\hline Secondary education & $13(5.3)$ & $77(31.2)$ & $7(2.8)$ & & & \\
\hline Tertiary education & $12(4.9)$ & $62(25.1)$ & $11(4.5)$ & & & \\
\hline \multicolumn{7}{|l|}{ Mother's education } \\
\hline No formal education & $3(1.2)$ & $7(2.8)$ & $1(0.4)$ & $2.799(8)$ & 0.946 & 246 \\
\hline Primary education & $7(2.8)$ & $37(15.0)$ & $6(2.4)$ & & & \\
\hline Secondary education & $12(4.9)$ & $74(30.1)$ & $12(4.9)$ & & & \\
\hline Tertiary education & $11(4.5)$ & $64(26.0)$ & $9(3.7)$ & & & \\
\hline \multicolumn{7}{|c|}{ Household Income (MYR) } \\
\hline$<1000$ & $4(1.6)$ & $7(2.8)$ & $3(1.2)$ & $11.451(8)$ & 0.177 & 246 \\
\hline $1001-2000$ & $8(3.3)$ & $24(9.8)$ & $2(0.8)$ & & & \\
\hline $2001-3000$ & $3(1.2)$ & $42(17.1)$ & $7(2.8)$ & & & \\
\hline $3001-4000$ & $6(2.4)$ & $36(14.6)$ & $7(2.8)$ & & & \\
\hline$>4001$ & $14(5.7)$ & $74(30.1)$ & $7(2.8)$ & & & \\
\hline \multicolumn{7}{|l|}{ Household Size } \\
\hline $1-3$ people & $3(1.2)$ & $21(8.4)$ & $3(1.2)$ & $1.026(6)$ & 0.985 & 250 \\
\hline 4 - 5 people & $22(8.8)$ & $110(44.0)$ & $18(7.2)$ & & & \\
\hline 6 - 7 people & $10(4.0)$ & $48(19.2)$ & $6(2.4)$ & & & \\
\hline > 8 people & $2(0.8)$ & $6(2.4)$ & $1(0.4)$ & & & \\
\hline
\end{tabular}

Chi-Square test *significant at $<.05$

Based on the findings, there were two variables, gender and ethnicity, that shows significant results with $X^{2}=8.794, p=.012$ and $X^{2}=13.147, p=0.024$, respectively. A study by Norhasmah et al. 
INTERNATIONAL JOURNAL OF ACADEMIC RESEARCH IN BUSINESS AND SOCIAL SCIENCES

Vol. 10, No. 15, Youth and Community Wellbeing: Issues, Challenges and Opportunities for Empowerment V1. 2020, E-ISSN: 2222-6990 @ 2020 HRMARS

(2004) has reported that, female secondary school student in Malaysia were significantly more concerned about the environment, but they were not significantly more committed to behaving more environmentally responsibly (Said, Yahaya, and Ahmadun, 2007).

Pearson's Chi-square was used, and the result showed that there was no association between all of the social demographic characteristic (gender, race, father's education, mother's education, household income and household size) with practice during haze among form 3 students and form 5 students. The $p$-value which was $>.05$, indicates that these variables are independent of the two variables. Thus, the null hypothesis was not rejected and that there is a no statistically significant relationship between the categorical variables.

Table 11: Association between socio-demographic with practice among Form 3 students

\begin{tabular}{|c|c|c|c|c|c|}
\hline \multicolumn{6}{|c|}{ Practice level, $n(\%)$} \\
\hline Gender & Poor & Good & $X 2(d f)$ & $p$-value & $\mathrm{N}$ \\
\hline Male & $13(20.6)$ & $\overline{16(25.4)}$ & $0.594(1)$ & 0.441 & 63 \\
\hline Female & $12(19.0)$ & $22(34.9)$ & & & \\
\hline \multicolumn{6}{|l|}{ Race } \\
\hline Malay & $23(36.5)$ & $36(57.1)$ & $1.583(2)$ & 0.453 & 63 \\
\hline Chinese & $1(1.6)$ & $2(3.2)$ & & & \\
\hline Indian & $1(1.6)$ & $0(0)$ & & & \\
\hline Others & $0(0)$ & $0(0)$ & & & \\
\hline \multicolumn{6}{|l|}{ Father's Education } \\
\hline No formal education & $0(0)$ & $0(0)$ & $1.591(1)$ & 0.207 & 35 \\
\hline Primary education & $0(0)$ & $0(0)$ & & & \\
\hline Secondary education & $3(8.6)$ & $8(22.9)$ & & & \\
\hline Tertiary education & $12(34.2)$ & $12(34.2)$ & & & \\
\hline \multicolumn{6}{|l|}{ Mother's education } \\
\hline No formal education & $0(0)$ & $0(0)$ & $1.458(2)$ & 0.482 & 35 \\
\hline Primary education & $0(0)$ & $1(2.9)$ & & & \\
\hline Secondary education & $5(14.3)$ & $9(25.7)$ & & & \\
\hline Tertiary education & $10(28.6)$ & $10(28.6)$ & & & \\
\hline \multicolumn{6}{|l|}{ Household Income (MYR) } \\
\hline$<1000$ & $1(2.9)$ & $0(0)$ & $4.193(4)$ & 0.381 & 35 \\
\hline $1001-2000$ & $1(2.9)$ & $3(8.6)$ & & & \\
\hline $2001-3000$ & $2(5.7)$ & $5(14.3)$ & & & \\
\hline $3001-4000$ & $2(5.7)$ & $5(14.3)$ & & & \\
\hline$>4001$ & $9(25.7)$ & $7(20.0)$ & & & \\
\hline \multicolumn{6}{|l|}{ Household Size } \\
\hline 1 -3 people & $0(0)$ & $2(5.7)$ & $3.925(3)$ & 0.27 & 35 \\
\hline 4 - 5 people & $8(22.9)$ & $5(14.3)$ & & & \\
\hline 6 - 7 people & $5(14.3)$ & $10(28.6)$ & & & \\
\hline$>8$ people & $2(5.7)$ & $3(8.6)$ & & & \\
\hline
\end{tabular}


INTERNATIONAL JOURNAL OF ACADEMIC RESEARCH IN BUSINESS AND SOCIAL SCIENCES

Vol. 10, No. 15, Youth and Community Wellbeing: Issues, Challenges and Opportunities for Empowerment V1. 2020, E-ISSN: 2222-6990 @ 2020 HRMARS

Table 12: Association between socio-demographic with practice among Form 5 students

\begin{tabular}{|c|c|c|c|c|c|}
\hline \multicolumn{6}{|c|}{ Practice level, n(\%) } \\
\hline Gender & Poor & Good & $X 2(d f)$ & $p$-value & $\mathrm{N}$ \\
\hline Male & $42(16.5)$ & $67(24.3)$ & $0.400(1)$ & 0.527 & 255 \\
\hline Female & $62(26.3)$ & $84(32.9$ & & & \\
\hline \multicolumn{6}{|l|}{ Race } \\
\hline Malay & $45(17.6)$ & $45(17.6)$ & $7.052(3)$ & 0.07 & 255 \\
\hline Chinese & $49(19.2)$ & $96(37.6)$ & & & \\
\hline Indian & $7(2.7)$ & $8(3.1)$ & & & \\
\hline Others & $3(1.2)$ & $2(0.8)$ & & & \\
\hline \multicolumn{6}{|l|}{ Father's Education } \\
\hline No formal education & $3(1.2)$ & $4(1.6)$ & $1.892(3)$ & 0.595 & 247 \\
\hline Primary education & $20(8.1)$ & $38(15.4)$ & & & \\
\hline Secondary education & $39(15.8)$ & $58(23.5)$ & & & \\
\hline Tertiary education & $39(15.8)$ & $46(18.6)$ & & & \\
\hline \multicolumn{6}{|l|}{ Mother's education } \\
\hline No formal education & $7(2.8)$ & $4(1.6)$ & $4.412(4)$ & 0.353 & 246 \\
\hline Primary education & 19(7.7) & $33(13.4)$ & & & \\
\hline Secondary education & $38(15.4)$ & $60(24.4)$ & & & \\
\hline Tertiary education & $35(14.2)$ & 49(19.9) & & & \\
\hline \multicolumn{6}{|l|}{ Household Income (MYR) } \\
\hline$<1000$ & $5(2.0)$ & $9(3.7)$ & $6.717(4)$ & 0.152 & 246 \\
\hline $1001-2000$ & $16(6.5)$ & $18(7.3)$ & & & \\
\hline $2001-3000$ & $20(8.1)$ & $32(14.6)$ & & & \\
\hline $3001-4000$ & $13(5.3)$ & $36(14.6)$ & & & \\
\hline$>4001$ & $46(18.7)$ & $51(20.7)$ & & & \\
\hline \multicolumn{6}{|l|}{ Household Size } \\
\hline $1-3$ people & $9(3.6)$ & $18(7.2)$ & $1.894(3)$ & 0.595 & 250 \\
\hline 4 - 5 people & $58(23.2)$ & $92(36.8)$ & & & \\
\hline 6 - 7 people & $28(11.2)$ & $36(14.4)$ & & & \\
\hline$>8$ people & $5(2.0)$ & $4(1.6)$ & & & \\
\hline
\end{tabular}

Chi-Square test

\section{Association between Knowledge, Attitude and Practice during Haze}

In this part, the association between knowledge and practice and attitude and practice. Hence, Chi-square test was used to analyse the data. Table 10 and Table 11 showed the tabulated data that was analysed.

About 14 (4.4\%) of the respondents showed good practice but has low knowledge on haze, however, $18(5.7 \%)$ of them showed poor practice during haze, but they have high knowledge on haze. The highest number of respondents showed good practice and have moderate knowledge at $145(45.6 \%)$, while the second highest number of respondents showed poor practice but also have moderate knowledge on haze at 103 (32.4\%). The Chi-square test showed that the $p$-value was .801 
INTERNATIONAL JOURNAL OF ACADEMIC RESEARCH IN BUSINESS AND SOCIAL SCIENCES

Vol. 10, No. 15, Youth and Community Wellbeing: Issues, Challenges and Opportunities for Empowerment V1. 2020, E-ISSN: 2222-6990 @) 2020 HRMARS

which was > .05 (which is the alpha level associated with a 95\% confidence level). Hence, there was no significant association between level of knowledge and the level of practice during haze, $X^{2}(2, N$ $=318)=0.444, p=.801$.

Table 13: Association between knowledge and practice

\begin{tabular}{cccccc}
\hline \multicolumn{6}{c}{ Level of Practice } \\
\hline & Poor & Good & $\begin{array}{c}\text { Pearson Chi- } \\
\text { Square (X2) }\end{array}$ & df & p-value \\
\hline Level of Knowledge & $8(2.5 \%)$ & $14(4.4 \%)$ & 0.444 & 2 & 0.801 \\
Hoderate & $103(32.4 \%)$ & $145(45.6 \%)$ & & & \\
High & $18(5.7 \%)$ & $30(9.4 \%)$ & & \\
\hline
\end{tabular}

$\mathrm{N}=318$, Chi-Square test

The highest number of respondents showed good practice during haze but with moderate attitude. About 31 (9.7\%) of the respondents have good practice along with good attitude towards haze, while 21 (6.6\%) of the respondents portray good practice during haze but with low knowledge on haze. Based on the Chi-square test done, the $p$-value was .018, which was $p<.05$. This showed that there was an association between level of attitude and level of practice, $X^{2}(2, N=318)=7.992$, $p=.018$. The null hypothesis was rejected and the result was significant. For the effect size of a chisquare independence test, Cramer's V was 0.159. Since Cramer's V takes on values between 0 and 1 , 0.159 indicates a very weak association.

Table 14: Association between attitude and practice

\begin{tabular}{ccccccc}
\hline \multicolumn{7}{c}{ Level of Practice } \\
\hline & Poor & Good & $\begin{array}{c}\text { Pearson Chi- } \\
\text { Square (X2) }\end{array}$ & df & p-value \\
\hline \multirow{2}{*}{ Level of Attitude } & Low & $23(7.2 \%)$ & $21(6.6 \%)$ & 7.992 & 2 & $0.018^{*}$ \\
& High & $9(2.8 \%)$ & $31(9.7 \%)$ & & & \\
& & $97(30.5 \%)$ & $137(43.1 \%)$ & & & \\
\hline
\end{tabular}

$\mathrm{N}=318$, Chi-Square test $*$ significant at $<.05$

The finding showed that there was an association between attitude and practice. This can be seen from many researches done before. Many studies have investigated factors related to consumer environmental behaviour, such as environmental knowledge (Bartkus et al. 1999; Gambro \& Switzky, 1996), attitudes (Simmons, 1998; Bradley et al., 1999; Hwang et al., 2000; Franzen, 2003), awareness (Strong, 1998), concern (Zimmer et al. 1994), activities (Palmberg \& Kuru, 2000; Tikka et al. 2000), behaviour (Pike et al. 2003), and demographic factors (Tikka et al. 2000) (Tolvanen et. al, 2012). A study by Tolvanen et al. (2012) shows that the practice of changing toothbrush has a statistically significant association at $p<.05$ level, with the attitude factors as well as improvement in practice, toothbrushing frequency, shows succesfull in terms of changing attitude. Similar findings were also 
obtained by Koeber et al. (2006), that shows an association between attitudes and behavior, but not between knowledge and behavior (Tolvanen et. al, 2012). On the other hand, there were also studies that disagree with this studies' finding, which is there is no significant relationship between attitude and practice. One of it is a study by Singh and Chapman (2011) shows that $83.7 \%$ of the respondents that has high and moderate level attitude did not correlate with practice of sharp disposal.

\section{Conclusion}

In conclusion, Form 3 students and Form 5 students were deemed to have moderate knowledge, attitude and practice on haze. Hence, it is recommended to enhanced the knowledge of these students as it could direct them towards a better attitude and practice during haze. Knowledge is the background factor that influence attitude towards behaviour, and thus the behaviour itself (Luszczynska and Sutton Daryl et al., 2002; Claessen et al., 2008; Tolvanen et. al, 2012). Therefore, learning more on how to achieve healthy behaviour, can change the health-related attitudes, and this can contribute to the improvement of the healthy practices (Tolvanen et. al, 2012). With that being said, increasing knowledge through enhancing environmental education, especially in schools, is important as it can guide students, the future generation, on ways to handle and sustain the environment for future use. Therefore, the infusion of environmental education in schools should be strengthen more so that students are more aware of the importance of environment for life sustainability. Hence, it is recommended to enhanced the knowledge of these students as it could direct them towards a better attitude and practice during haze, and this can be done by reviewing the Environmental Education (EE) taught in school syllabus.

Some limitation on this study was that the children might not be telling the truth while answering the questions, particularly questions pertaining attitude and practices and this can lead to social desirability bias. However, this limitation can be overcome by convincing them that their anonymity will be kept confidential. Other than that, the data were only taken from one school, hence, it may not represent the population of Selangor as expected. For this, increase the study location to various schools from different districts, so as to have a more diverse sample that will represents Selangor population.

\section{Acknowledgement}

The authors would like to thank the Ministry of Education (MOE) for giving out permission to conduct the research at SMK Perimbun, and to the school as well for giving further permission to continue conducting the research on secondary school students. Next, a massive appreciation to all the teachers, that were able to distribute the questionnaire and convinced the students into taking part in this research. Finally, the author would like to show gratitude to all the respondents, the form 3 and form 5 students who willingly participated in this research and spending their precious time answering the questionnaires given. All in all, a big thank you to all parties that helps ease the process of data collection.

\section{Reference}

Al Binali, A. M., Mahfouz, A. A., Al Fifi, S., Naser, S. M., \& Al Gelban, K. S. (2010). Asthma knowledge and behaviours among mothers of asthmatic children in Aseer, south-west Saudi Arabia. 
INTERNATIONAL JOURNAL OF ACADEMIC RESEARCH IN BUSINESS AND SOCIAL SCIENCES

Vol. 10, No. 15, Youth and Community Wellbeing: Issues, Challenges and Opportunities for Empowerment V1. 2020, E-ISSN: 2222-6990 @) 2020 HRMARS

Eastern Mediterranean Health Journal, 16(11), 1153-1158. https://doi.org/10.26719/2010.16.11.1153

Chu, M. M. (2019). 'Stop the Johan Setia open fires.' Retrieved November 12, 2019, from https://www.thestar.com.my/news/nation/2019/09/23/stop-the-johan-setia-open-fires

Hammami, M. B. A., Mohammed, E. Q., Hashem, A. M., Al-Khafaji, M. A., Alqahtani, F., Alzaabi, S., \& Dash, N. (2017). Survey on awareness and attitudes of secondary school students regarding plastic pollution: implications for environmental education and public health in Sharjah city, UAE. Environmental Science and Pollution Research, 24(25), 20626-20633. https://doi.org/10.1007/s11356-017-9625-x

Ho, A. F. W., Mbbs, S., Zheng, H., Silva, D. A. De, Wah, W., \& Earnest, A. (2018). The Relationship Between Ambient Air Pollution and Acute Ischemic Stroke: A Time-Stratified Case-Crossover Study in a City-State With Seasonal Exposure to the Southeast Asian Haze Problem. Annals of Emergency Medicine. https://doi.org/10.1016/j.annemergmed.2018.06.037.

Kaliyaperumal, K., Expert, I. E. C., \& Project, D. R. (2004). Guideline for Conducting a Knowledge, Attitude and Practice (KAP) Study.

Lateh, H., \& Muniandy, P. (2010). Environmental education (EE): Current situational and the challenges among trainee teachers at teachers training institute in Malaysia. Procedia - Social and Behavioral Sciences, 2(2), 1896-1900. https://doi.org/10.1016/j.sbspro.2010.03.1005

Mat Zin, R. (2007). Understanding the Formulation of the Revised Poverty Line in Malaysia. Akademika, 70(1), 21-39.

Ministry of Education. (2019). Kenyataan Media: Laporan Penutupan Sekolah Akibat Jerebu Pada 19 $\begin{array}{lllll}\text { Dan } & 20 & \text { September } & 2019 . & \text { Retrieved from }\end{array}$ https://www.moe.gov.my/pemberitahuan/kenyataan-media/maklumat-penutupan-sekolahakibatjerebu-pada-18-september-2019-rabu-sehingga-1-00-petang

Norela, S., Saidah, M. S., \& Mahmud, M. (2013). Chemical composition of the haze in Malaysia 2005. Atmospheric Environment, 77, 1005-1010. https://doi.org/10.1016/j.atmosenv.2013.05.024

Othman, J., Sahani, M., Mahmud, M., \& Sheikh, K. (2014). Transboundary smoke haze pollution in Malaysia: Inpatient health impacts and economic valuation. Environmental Pollution, 189, 194201. https://doi.org/10.1016/j.envpol.2014.03.010

Pretto, L. De, Acreman, S., \& Ashfold, M. J. (2015). The Link between Knowledge, Attitudes and Practices in Relation to Atmospheric Haze Pollution in Peninsular Malaysia, 1-18. https://doi.org/10.1371/journal.pone.0143655

Qian, X., Xu, G., Li, L., Shen, Y., He, T., Liang, Y., \& Yang, Z. (2016). Knowledge and perceptions of air pollution in Ningbo, China, (December 2013), 1-7. https://doi.org/10.1186/s12889-0163788-0

Rahman, S. A., Hamzah, M. S., Elias, M. S., Salim, N. A. A., Hashim, A., Shukor, S., ... Wood, A. K. (2015). A long term study on characterization and source apportionment of particulate pollution in klang valley, kuala lumpur. Aerosol and Air Quality Research, 15(6), 2291-2304. https://doi.org/10.4209/aaqr.2015.03.0188

Redmond, G., Praino, R., \& Siddiquee, N. (2016). Child deprivation in Malaysia, (August), 1-114.

Said, A. M., Yahaya, N., \& Ahmadun, F. R. (2007). Environmental comprehension and participation of Malaysian secondary school students. Environmental Education Research, 13(1), 17-31. https://doi.org/10.1080/13504620601122616 
Singh, A. P., \& Chapman, R. S. (2011). Knowledge, Attitude and Practices (Kap) on Disposal of Sharp Waste, Used for Home Management of Type-2 Diabetes Mellitus, in New Delhi, India. Journal of Health Research, 25(3), 135-140.

Tolvanen, M., Lahti, S., Miettunen, J., \& Hausen, H. (2012). Relationship between oral health-related knowledge, attitudes and behavior among 1516-year-old adolescents - A structural equation modeling approach. Acta Odontologica Scandinavica, 70(2), 169-176. https://doi.org/10.3109/00016357.2011.600722.

Wong, Y. A., Mukari, S. Z. M. S., Harithasan, D., \& Mazlan, R. (2019). Knowledge and attitude on childhood hearing loss among mothers and mothers-to-be in urban and rural areas in Malaysia. International Journal of Pediatric Otorhinolaryngology, 124, 79-84.

Yezli, S., Yassin, Y., Mushi, A., Maashi, F., Aljabri, N., Mohamed, G., Alotaibi, B. (2019). Knowledge, attitude and practice (KAP) survey regarding antibiotic use among pilgrims attending the 2015 Hajj mass gathering. Travel Medicine and Infectious Disease, 28(April 2018), 52-58. https://doi.org/10.1016/j.tmaid.2018.08.004 